\title{
Sob o signo da ambuiguidade: uma análise de Anchieta, José do Brasil
}

////////////////// Carlos Eduardo Pinto de Pinto ${ }^{1}$

1. Mestre em História Social da Cultura pela Pontifícia Universidade Católica do Rio de Janeiro. Doutor em História pela Universidade Federal Fluminense. Possui artigos publicados sobre a representação da história e do Rio de Janeiro pelo Cinema Novo. E-mail: dudachacon@yahoo.com.br 


\section{Resumo}

Anchieta, José do Brasil (Paulo César Saraceni, 1979) é considerado o primeiro filme histórico do Cinema Novo a ser produzido pelo Estado, via Embrafilme. Em seu circuito de produção e exibição, os "sentidos históricos" que o filme veicularia foram disputados pela Igreja Católica, pela ditadura civil-militar, pelo Cinema Novo, por críticos e teóricos. A obra mostra-se, portanto, um vetor de reflexão sobre a cultura histórica brasileira do período, caminho seguido pelo artigo.

Palavras-chave

Cinema Novo, filme histórico, ditadura civil-militar, cultura histórica.

Abstract

Paulo César Saraceni’s Anchieta, José do Brasil (1979) [Anchieta, Brazil's José] is considered the first Cinema Novo's historic film produced with governmental aid, by Embrafilme. On its production and exhibition circuit, the "historical representation" enacted by the movie was disputed by the Catholic Church, the civil-military dictatorship, the Cinema Novo itself, critics and theorists. As such, it is an important vector to think on the Brazilian historical culture at that time, path followed by this article.

Keywords

Cinema Novo, historic film, civil-military dictatorship, historical culture. 
Disputas em torno da construção de sentidos de um filme são bastante comuns na história do cinema. $\mathrm{Na}$ acepção de Roger Odin (2005), nesse processo se dá o encontro de modos de ver aqueles inerentes à obra, cuja detecção é possibilitada pela análise do "específico fílmico" (KORNIS, 1992; MORETTIN, 2003), e os que são mobilizados por seus diversos públicos. Pela perspectiva de Semiopragmática, defendida por Odin, menos que contrapor uma série de interpretações sobre o filme, que virtualmente teria um sentido primário a ser apreendido, trata-se de mapear os sentidos criados com o filme, em regimes "espectatoriais" diversos. Para algumas obras, esse encontro de modos de ver poder ser pacífico e satisfatório para todos os setores envolvidos. Em torno de outras, travam-se aguerridas batalhas pela construção de seu sentido, como apontei no início deste parágrafo. É esse o caso de Anchieta, José do Brasil (Paulo César Saraceni, 1977), filme analisado aqui.

A obra trata da biografia de José de Anchieta e da miscigenação cultural, temas caros à ditadura civil-militar instaurada em 1964, mas assume perspectivas diegética e narrativa em parte contrárias à visão conservadora. Não se trata, de forma alguma, de um filme absolutamente contestador, mas de uma obra ambígua, que desliza e se adequa às polaridades mobilizadas em seu circuito social, que não eram poucas. Afinal, a obra foi disputada pela Embrafilme, empresa estatal de cinema que a coproduziu e distribuiu; pela Igreja Católica, interessada na beatificação de Anchieta; pelo Cinema Novo - em fase de revisão de seus postulados políticos e estéticos -, por parte tanto de Saraceni quanto de alguns de seus pares, 
2. As traduções para o português neste artigo foram feitas pelo autor. que questionavam suas intenções ao realizar a obra; finalmente, por críticos e teóricos, voltados para a discussão da natureza do filme histórico, num esforço de definição do gênero e de sua importância no cenário da produção cinematográfica brasileira da década.

Embora para alguns desses setores a biografia do então candidato à beatificação estivesse diretamente em jogo, defendo que o tema principal dos debates tenha sido a ideia de história, num momento em que a cultura histórica brasileira ganhava a atenção. Essa relação que uma sociedade mantém com seu passado, pautada não apenas pela historiografia mas também pela cultura política (GOMES, 2007), foi intensamente trabalhada pela política cultural construída pela ditadura civil-militar ao longo da década. Não se deve esquecer o poder do simbólico, já que, como postula Serge Berstein (1992, p. 69), “[... ] na ordem da cultura política, é a lenda que é a realidade, pois é ela que é mobilizadora e determina a ação política concreta, à luz da representação que ela propõe"2. Tratava-se de erigir um aparato de legitimação em que as ideias de história e memória se confundiam (PINTO, 2005), voltado para o ensino de história em seus diversos níveis, para os museus, para as cidades históricas e para os filmes históricos. Sempre a partir de uma perspectiva reverenciadora das "glórias", dos "grandes vultos" e dos "heróis" para lançar mão de uma terminologia bastante em voga.

Anchieta, José do Brasil e seu circuito social formam, dessa maneira, um excelente vetor de reflexão sobre a cultura histórica brasileira do período, apontando um caminho que pretendo seguir ao longo deste texto.

\section{A natureza do "filme histórico" e sua presença no cinema brasileiro}

O cinema e a história podem se encontrar de muitas formas, construindo uma “relação de diversos andares" (LEUTRAT, 1995) ao ritmo dos conectivos e preposições: história (no/do/através do) cinema. Neste artigo, as três relações se conjugam; afinal ;produzo conhecimento histórico através do cinema, por meio da abordagem de um filme histórico - um meio de representação cinematográfica da história - , ao mesmo tempo que me atenho a reflexões pertinentes à história do cinema (brasileiro). 
Entre as relações apontadas acima, uma que merece mais a atenção é o "filme histórico". O termo, falsamente transparente, encobre uma gama variada de tipos de produção cinematográfica. Cristiane Nova (2000) propõe um espectro que inclui reconstituições, biografias, filmes de época, ficções históricas, filmes-mito e filmes etnográficos, além de adaptações literárias e teatrais. De forma bastante ampla, portanto, pode-se considerar como "filme histórico" aquele que realiza, em algum nível, uma representação do passado, tomando como referência o tempo em que é feito - sem deixar de acrescentar, às possibilidades listadas pela autora, os documentários. Essa primeira aproximação, contudo, ainda se mostra falha no que se refere à relação que as obras podem estabelecer com a história. Afinal, existem muitas possibilidades de combinação entre fidelidade às pesquisas acadêmicas e uso de doses variadas de ficção. Assim, e para ficar apenas nos extremos, um filme pode ser vendido como reconstituição e operar somente com imagens e ações que "pareçam" históricas; outro pode se assumir como "imaginação" e apresentar um alto nível reflexivo sobre o tema que aborda.

Importante salientar que, qualquer que seja o resultado da equação esboçada acima, filmes históricos possibilitam, se não uma “aprendizagem”, ao menos a experimentação de algum contato sensorial, intelectual, emocional - com o passado. Desse modo, o cinema se constitui como agente de criação de sentidos históricos, sendo mais do que um meio de divulgação - uma vez que colocar a relação nesses termos pressuporia um saber histórico pronto a ser propagado, ao passo que o cinema seria encarado apenas como um dispositivo propagador. Muitas gerações travaram contato com o passado através de ficções desse tipo, aproximando-se do que David Lowenthal (1988, p. 229) denominou factions - híbrido de fato (fact, no original) e ficção (fiction). Embora o autor trate dos romances históricos em voga no século XIX, acredito que o paralelo com os filmes históricos seja possível. Afinal, o mesmo desejo dos leitores de unir biografia e história, de vivenciar o passado e se identificar com personagens vivas, que comem, bebem, amam e têm raiva parece animar os espectadores dos filmes. 
A partir dessa definição, é possível identificar que o gênero sempre esteve presente na cinematografia brasileira, desde a fase muda (MACHADO, 1987) até hoje. Mesmo que todos os períodos apresentem debates e disputas em torno da representação cinematográfica da história, é possível afirmar que, naqueles em que governos autoritários estavam no poder, a sensibilidade diante dos filmes históricos foi mais aguçada. É o caso do Estado Novo, entre 1937 e 1945 (MORETTIN, 2000) e da ditadura civil-militar (1964-1985), mais especificamente a década de 1970, em que tanto o Estado quanto os cinemanovistas apresentaram acentuado interesse no gênero.

Os cinemanovistas, em sua maioria, realizaram "filmes históricos modernos" ou "inovadores" (ROSENSTONE, 2010, p. 36). Tais obras são caracterizadas por se apropriarem de forma crítica e reflexiva dos discursos históricos, questionando a história oficial e, não raro, se questionando sobre o próprio sentido da história (XAVIER, 2001). No cinema brasileiro, como indicado acima, foram realizadas prioritariamente pelos cinemanovistas ou, de forma mais inclusiva, por aqueles comprometidos com o cinema moderno.

\section{A geração do Cinema Novo e o "desejo de história"}

Além de Paulo César Saraceni, entre os integrantes do Cinema Novo estavam Glauber Rocha, Nelson Pereira dos Santos, Cacá Diegues, Leon Hirszman, Joaquim Pedro de Andrade, Ruy Guerra, Walter Lima Jr., Zelito Viana, Gustavo Dahl, David Neves e Eduardo Coutinho. Eram relativamente jovens quando o movimento começou a se delinear, pertencendo todos à geração de 1964 (PINTO, 2011), que para Denise Rollemberg tinha como marcos fundadores "os movimentos reformistas e o golpe civil-militar que depôs o presidente João Goulart" (ROLLEMBERG, 1999, p. 493).

3. A autora não se refere aos cinemanovistas, mas aos exilados políticos da ditadura civil-militar, seu objeto de estudo.
O "novo cinema" brasileiro deveria representar, simultaneamente, uma luta contra a dominação do mercado nacional pelo cinema norte-americano e a tentativa de "capturar" 
a realidade brasileira, não apenas através das temáticas dos filmes como também pela criação de novas maneiras de filmar que fossem genuinamente nacionais (XAVIER, 2001; FIGUEIRÔA, 2004). Se essa é a contribuição dos reformismos, o golpe de 1964 atingiu - para além dos posicionamentos políticos mais evidentes - a relação que estabeleciam com a história, o que me interessa prioritariamente aqui.

Para esses criadores, a história só tinha um caminho a seguir - a mudança - cabendo a eles efetivar o processo. No caso dos jovens cineastas, a sua arte era considerada a principal arma: faziam filmes como quem faz história. E os debates históricos sempre estiveram presentes em suas falas, ainda que como uma sombra, perpassando os propósitos com que essa geração filmava. O desejo de conhecer e simultaneamente apresentar o Brasil para os brasileiros incluía necessariamente o reconhecimento do seu passado. Como Ismail Xavier (2001, p. 127), escrevendo sobre Glauber Rocha, afirmou: trata-se de "uma geração de intelectuais e artistas brasileiros marcados por uma aguda consciência histórica, sempre atenta à ligação do cultural com o político", o que pode ser corroborado pela análise que Maurício Cardoso (2011) faz de História do Brasil (Glauber Rocha e Marcos Medeiros, 1974).

A insubordinação da história tornara-se palpável a partir do ponto em que, em 1964, ela se recusou a seguir os rumos determinados pelos jovens (REIS FILHO, 1991). O ano de 1968, com a assinatura do AI-5 e o reforço da repressão, surgia para essa geração como a conclusão do golpe dado quatro anos antes. Os caminhos apresentados a partir desse ponto eram perigosos, mas precisariam ser trilhados: menos que lutar contra a ditadura, tentar driblá-la parecia ser a trilha encontrada para continuar criando. Uma das maneiras de pisar nesse terreno era dialogar com as demandas ditatoriais, o que era o caso dos filmes históricos. Porém, é preciso reforçar que já havia nos filmes e nas falas dos componentes dessa geração um desejo de história que não se manifestara somente após os golpes, sendo mesmo um de seus traços definidores. 
4. Movimento surgido no seio da Igreja Católica, que tende a revisar a teologia política, procurando usar os ensinamentos cristãos em prol da superação da dependência econômica e da exploração dos oprimidos. Os seus adeptos se empenharam na luta conta a ditadura civil-militar no Brasil, procurando defender os Direitos Humanos dos militantes perseguidos.

5. O padre espanhol Pedro Casaldáliga se radicou no Brasil em 1968, sendo nomeado bispo no início da década de 1970. Adepto

da Teologia da Libertação, foi perseguido pela ditadura, por conta de sua defesa dos Direitos Humanos.

\section{A vida de Anchieta daria um filme...}

Paulo César Saraceni foi responsável por alguns marcos do Cinema Novo, o que fez que se tornasse respeitado e admirado pelos companheiros. Realizou o primeiro curta considerado um filme profissional do Cinema Novo, finalizado enquanto ele estudava no Centro Sperimentale di Cinematografia, em Roma. Já O desafio (1965) foi considerado por muitos autores como o inaugurador da representação urbana no Cinema Novo (RAMOS, 1987; PINTO, 2013b), em que ousou refletir abertamente sobre o golpe de 1964 (CAMPO, 1995; 2011).

A partir de 1975 já começaria a se delinear o projeto de Anchieta, José do Brasil, o primeiro filme histórico cinemanovista coproduzido pela Embrafilme. Segundo a autobiografia de Saraceni (1993, p. 283), primeiro veio “[...] a ideia de fazer um filme sobre nossas origens", finalmente concretizada no tema de Anchieta, sem ficar claro o porquê dessa escolha. É importante salientar que a memória do jesuíta foi resgatada pela ditadura civil-militar, que em 1965 instituiu o dia 9 de junho para sua celebração (FLECK; MATOS, 2010), organizando uma Comissão Nacional responsável por fomentar atividades em torno do tema, incluindo um acordo com a UnB para a realização de um filme, que não viria a ser realizado.

Independentemente da origem de suas ideias, Saraceni teria se mostrado tácito no esforço de construir, com seu filme, "outro" Anchieta, diferente daquele que interessaria à igreja tradicional e à ditadura: "Leio os livros que trouxe da Europa, começo a visualizar um Anchieta catequizado pelos índios" (SARACENI, 1993, p. 289). Ainda segundo sua memória, o "seu" Anchieta estaria associado à Teologia da Libertação ${ }^{4}$ e a dom Pedro Casaldáliga ${ }^{5}$, havendo mesmo trechos em que o associa a Luís Carlos Prestes. Tratava-se, portanto, de uma tentativa de "esquerdização" (embora mantendo o caráter religioso, ao menos nos dois primeiros casos). Essa postura já indica a forma de construção da narrativa fílmica, que mantém um diálogo mais profícuo com a memória erigida em torno do jesuíta do que com a historiografia a seu respeito. 


\section{O início da produção: disputas}

Em 1975, a Embrafilme criou uma comissão para escolher projetos de filmes históricos. É importante perceber que essas propostas já estão coadunadas com uma política cultural mais elaborada, surgida a partir da implementação da PNC (Política Nacional de Cultura), cujo objetivo era formar um projeto homogêneo de política cultural no país. A concepção de cultura presente na PNC era de inspiração claramente antropológica, sendo encarada como "a plenitude da vida humana no seu meio" (RAMOS, 1983, p. 119). Estava fortemente baseada nas ideias dos intelectuais conservadores reunidos em torno do CFC (Conselho Federal de Cultura), criado já em 1965 e formado por profissionais egressos dos Institutos Históricos e Geográficos e das Academias de Letras. A base de sua concepção era a miscigenação cultural, como desenvolvida por Gilberto Freyre.

Saraceni enviaria o roteiro de Anchieta para o projeto da Embrafilme, sendo, finalmente, o único filme realizado. O diretor lembra que sofreu pressões do ministro da Educação, Ney Braga, bem como do diretor da Embrafilme, Roberto Farias, e de seu assessor, Zelito Viana, para que mandasse o roteiro de Anchieta. Diante disso, teria ficado ressabiado: "Deve haver uma manobra política aí que eu não estou gostando; se eu fizer Anchieta, vou fazer o meu Anchieta, e não o do ministro ou de qualquer um" (SARACENI, 1993, p. 295).

A desconfiança tinha a sua razão de ser. Desde o início da década, a ditadura mostrava interesse pelos filmes históricos, como indica o discurso do então ministro da Educação, Jarbas Passarinho, incentivando os cineastas a filmarem o "nosso glorioso passado histórico” (FILME CULTURA, 1971). Tratava-se de um incentivo à realização de filmes ufanistas, seguindo a fórmula do épico clássico, que tem, entre suas características, a grandiosidade e o tom espetacular (VADICO, 2012). Se essa diretiva poderia ser apenas intuída em 1971, ela ficaria clara no ano seguinte, quando o próprio presidente Médici encampou a obra Independência ou morte (Carlos Coimbra, 1972), superprodução sem qualquer vínculo com o Estado, mas completamente coerente com o 
6. O autor cita trecho da matéria "A glória do cinema para Passarinho", Jornal da Tarde, 11 set. 1970. clima de celebração nada crítica em torno do sesquicentenário da Independência (PINTO, 2005, 2005b).

Ao investir em filmes históricos, único gênero a ganhar uma atenção especial (RODRIGUES, 1987), a Embrafilme surgia como a face mais evidente do dirigismo cultural. Por outro lado, a estatal funcionava como uma espécie de banco financiador, o que era uma relação bem-vinda. Por exemplo, em 1970, após uma reunião entre ministros, produtores e cineastas (entre outros, Glauber Rocha, Joaquim Pedro de Andrade e Luís Carlos Barreto), foi declarado enfaticamente que ao ministro Jarbas Passarinho caberia a "glória de implantar uma indústria cinematográfica brasileira" (RAMOS, 1983, p. 95$)^{6}$.

Os atritos entre Saraceni e a Embrafilme tendiam a se acirrar no decorrer das filmagens. O diretor queria realizar o filme em Porto Seguro, na Bahia, "[...] único lugar onde havia um clima de século XVI", diria em uma entrevista a Alex Viany (1999, p. 339), mas também porque a distância lhe daria mais liberdade, segundo sua autobiografia (SARACENI, 1993). Alegando os altos custos dessa operação, a Embrafilme não permite, mas ainda assim Saraceni insiste e viaja com sua equipe, relatando que havia atrasos propositais na liberação das verbas, o que fez que precisasse de apoio do governo de Porto Seguro para continuar os trabalhos. No retorno, com apenas $70 \%$ das filmagens realizadas, ocorreria um incidente envolvendo prisões e drogas que viria a ter bastante repercussão na mídia e abalaria ainda mais as relações.

Depois desse episódio, a Embrafilme apreendeu o material. "Fiquei oito meses esperando a decisão [...]. Ou eu acabava o filme ou me davam o copião para eu conseguir meios de acabar de fazêlo" (SARACENI, 1993, p. 307). A obra foi finalizada, depois de se realizar as últimas filmagens em Paraty, Estado do Rio. O filme pronto foi exibido para uma comissão formada por Roberto Farias, Ney Braga e padre Hélio Abranches Viotti. Embora o ministro não tenha se manifestado diretamente, Saraceni ficou sabendo por Roberto Farias que ele havia implicado com uma cena de nudez frontal masculina. Já o padre Viotti aprovou o filme, entregando ao diretor um pequeno texto, que Saraceni reproduz: “A figura 
do Apóstolo do Brasil foi tratada com simpatia constante, com dignidade e na intenção de apresentá-lo como santo, a caminho dos altares" (SARACENI, 1993, p. 314). Mesmo sem corresponder ao que a empresa estatal esperava, um espetáculo histórico nos moldes de Independência ou morte, o filme foi liberado para a exibição.

\section{Análise: o "específico” de um filme ambíguo}

Fruto de um cruzamento insólito, Anchieta, José do Brasil resulta de uma relação entre antagonistas e carrega as marcas dessa ambiguidade. Por um lado, tende a ser uma reconstituição histórica clássica e, por outro, se mostra bastante experimental. Embora apresente uma estrutura "início-meio-fim" bem delimitada, use cenários de época e as atuações procurem dar profundidade psicológica aos personagens, em muitas sequências a narrativa "jorra aos borbotões", se estendendo em cadeias de imagem e música fluidas que em nada lembram o didatismo das produções históricas clássicas que a ditadura procurava incentivar. Assim ocorre já no início, com as imagens que passo a descrever agora, tentando manter, na escrita, o mesmo tom telegráfico usado em sua narrativa:

Mulher amamentando uma criança - tela escura -, pegadas na areia - mar - , um texto de Anchieta que finaliza com "Só a heróis compete tantas glórias" - nome do filme -, mar (música instrumental), créditos, o mar sempre ao fundo, fim dos créditos (a música continua), pátio interno de uma casa, voz de Anchieta em over narrando em primeira pessoa que nasceu nas Ilhas Canárias, falando do pai (imagem do pai - quadro fixo, câmera parada), falando da mãe (quadro fixo, a música cessa), "Sou um afro-castelhano [...], o que me ligaria mais tarde aos índios brasileiros" (volta a música, quadro em plano aberto), mão em gesto de despedida segurando um chapéu, a voz em over explicando que se trata do pai se despedindo do filho que iria estudar em Coimbra, "Deixo Tenerife para nunca mais voltar" - a mãe encara a câmera (quadro fixo), "Vivo em pleno esplendor do Renascimento [...]. Gosto de escrever poesias e declamá-las para meus amigos". A voz continua em over, mas já posso ver Ney Latorraca, o intérprete do padre jesuíta. 
Esse fluxo inicial segue veloz, sem pausas, porque não parece ser nele que se encontra o que mais interessa, mas sim o primeiro êxtase místico de Anchieta. Em seguida, a cena que esclarece o envio do padre para o Brasil e sua reação desanimada, pois então os trópicos pareciam um jugo muito pesado para um religioso à beira da morte. Já no Brasil, outra sequência-córrego. Plano aberto, mise-en-scène bem evidente: praia, índios de costas, cavalos, soldados. A voz de Anchieta em over informa se tratar da Bahia. O governador-geral desembarca, índios avançam em direção a ele, o cercam, vê-se o mal-estar estampado na expressão de seu rosto, a câmera se desloca - desestabilizando o quadro bem montado - , vai para o meio da multidão de nativos, filma de perto, cria closes, sempre em movimento constante, e se afasta novamente. Anchieta aparece na praia, os índios fazem os mesmos movimentos de boas-vindas que ofereceram ao governador-geral, sendo que o padre reage bem, sorri (acompanhado de uma música instrumental extradiegética, com tonalidades românticas). O jesuíta passeia com os índios, deixa que eles o toquem e recebe os objetos que lhe ofertam, inclusive uma lança.

Mais adiante, o encontro com José da Nóbrega, o superior da Companhia de Jesus no Brasil. Segue-se uma conversa entre eles, na qual o subalterno desfila todas as boas impressões que a nova terra e seus habitantes lhe deixaram. A união das sequências em que Anchieta se mostra familiarizado com a cultura local e misticamente integrado à natureza do Brasil com essa sequência em que conversa com José da Nóbrega funciona como a defesa de que a união com os índios deveria ser o caminho seguido pelos colonizadores no Brasil, de acordo com a opinião do padre.

$\mathrm{Na}$ porção final do filme, os negros também aparecem. Em viagem a Pernambuco, Anchieta trava contato com uma corte branca envolvida em "luxos orientais", enquanto são servidos por negros escravizados. As orgias são filmadas com a câmera quase parada, sendo perceptível apenas um leve movimento na horizontal (como se eu, que vejo, estivesse movimentando a cabeça de um lado para o outro, mas de maneira muito contida). Os atores não falam, apenas se movimentam, riem, comem, se beijam, desfilam 
usando figurinos luxuosos. A música extradiegética cresce em intensidade, aproximando-se da lógica dos mantras. Em seguida, Anchieta aparece se referindo à precariedade com que os negros escravizados eram tratados e ao fato de não serem batizados.

Presente na montagem fluida da abertura, nos enquadramentos em plano aberto contendo uma mise-en-scène bastante explícita, na câmera na mão e no tom brechtiano das atuações, a estética cinemanovista pode ser bem observada nas sequências que reforçam a teatralidade do filme. Por exemplo, num trecho em que uma mulher compra uma índia, encenação interrompida pela inserção de outra sequência, em que Anchieta aparece ao lado de Manoel da Nóbrega, os dois encostados em uma cerca, olhando para a câmera. Anchieta diz que gostaria de escrever um auto em que a mesma dona Maria José, que acabou de comprar a índia, lhe daria liberdade. Tal afirmação vem conectar o esquematismo da montagem do filme ao esquematismo didático utilizado pelo padre nas suas peças teatrais.

Essa proposta é logo confirmada pelas sequências em que vejo alguns dos personagens da trama declamando como se estivessem fazendo parte de autos nos quais se poderia ver, nas palavras de José de Anchieta, a "formação do Brasil". Ao fim, a inspiradora dos autos, dona Maria José, finalmente aparece dando liberdade à índia comprada: "O Brasil [...] me deu poder. Eu acorrento porque não quero ser acorrentada". Como que seguindo o mesmo clima dos autos, o perigo da presença protestante é representado pela figura de Jean de Boulés, com quem Anchieta e Nóbrega dialogam, organizados em uma mise-en-scène muito próxima da que é dispensada à representação dos autos.

$\mathrm{Na}$ porção final do filme, são apresentados também alguns transes místicos do padre, cada vez mais frequentes no fim da vida. A sequência que representa a sua morte é filmada de forma lenta, enquanto no som extradiegético ouvem-se música e um poema declamado pela voz de Anchieta em over. O seu enterro é representado como um grande acontecimento, com a câmera se movimentando em meio ao cortejo numeroso, se misturando aos presentes. Os sons dos sinos que anunciavam o enterro vão sendo 
aos poucos substituídos por batuques extradiegéticos e apitos. Figurantes agitam estandartes, como num desfile de Carnaval. A impressão é confirmada quando percebo o padre sentado sobre a liteira que deveria levar seu corpo: Anchieta está vivo, sorrindo e observando o cortejo, como se fosse um destaque de carro alegórico. A música fica cada vez mais frenética, com presença de sax e elementos eletrônicos. As imagens, em contraste, começam a ser mostradas em “câmera lenta”. Os créditos finais sobem.

\section{Circulação: um filme para todos os gostos}

No espaço de comunicação do filme (ODIN, 2005, 2011), devem ser consideradas as expectativas em torno do projeto, bem como as afirmações de Saraceni sobre o que pretendia fazer com a obra. Em ambas as situações, o discurso religioso teve importância (MALAFAIA, 1998; FLECK; MATOS, 2010), mas não será foco de minhas observações. No espaço deste artigo, o que mais interessa é perceber que na campanha de Saraceni pela beatificação está implícita uma releitura da história, intentada através de recursos fílmicos e reforçada pela divulgação da obra. Nesse jogo, as regras do filme histórico clássico são associadas à ditadura e à Embrafilme (e a qualquer outro grupo ou instituição conservadores), enquanto a releitura livre que ele realizaria de Anchieta definiria uma postura militante, de um cineasta identificado com as esquerdas. Tratase, portanto, de um esforço de "desmonumentalização", como apresentado por Eduardo Morettin (2001) e Marcos Napolitano (2011), mas realizado concomitantemente a disputas em torno da reinvenção do mito. Afinal, com seu filme, Saraceni também disputava espaço pela releitura da biografia de Anchieta. Por mais que pareça nonsense, o diretor e roteirista "desmonumentalizava" para tentar monumentalizar de outra forma.

Ao fim, a tese do filme se completa: Anchieta surge como o pivô de união das três raças durante o período colonial. Essa leitura histórica está de acordo com a política cultural desenvolvida a partir de 1975, momento em que os governos ditatoriais passaram a apresentar postura mais propositiva nesse campo. O que antes era intuído pela atuação dos órgãos de censura (que esclareciam 
o que não era possível fazer), passou a ser apresentado de forma mais sistemática a partir da implementação da Política Nacional de Cultura, já comentada. Contudo, o filme não é apreendido como entreguista, servindo de defesa à sua idoneidade a linguagem moderna de que se utiliza - maior indício de sua estratégia de "desmonumentalização" - , que tanto incomoda à Embrafilme, mediadora entre os cineastas e o governo (AMANCIO, 2001; RODRIGUES, 1987). Logo, imperou a ambiguidade.

O espaço crítico corrobora tal impressão. Em texto contemporâneo ao lançamento da obra, mas referindo-se à atuação dos críticos diante dos filmes históricos produzidos ao longo da década, Jean-Claude Bernardet parte da hipótese de que os críticos trabalham com um complexo de ideias, tais como naturalismo, ciência e grandiloquência. O naturalismo pretendia uma aproximação da história real. A ciência daria embasamento ao naturalismo, pois só calcado em pesquisas um cineasta poderia fazer uma boa reconstituição de época. Enfim, a grandiloquência seria exigida pelo fato de os críticos não admitirem que enredos "menores" fossem filmados: a história, sendo nobre, precisaria contar com personagens igualmente nobres, filmados de forma adequada, ou seja, espetacular (BERNARDET, 1979). A rejeição aos filmes históricos modernos se daria, portanto, pela exigência de que seguissem tais parâmetros, associados aos filmes históricos clássicos.

No caso de Anchieta, um filme "rompido com o naturalismo e afastado de qualquer intenção de reconstituição" (BERNARDET, 1979 , p. 58), o autor encontra um bom exemplo. Afinal, ao mesmo tempo que foi criticado "pelas falhas do naturalismo, da reconstituição, da reprodução", foi igualmente elogiado "pelas qualidades da reconstituição" (BERNARDET, 1979, p. 58). Por certo que isso se dá pela mobilização de diferentes modos de ver por parte da crítica - como fica claro no embate entre Ely Azeredo, do Jornal do Brasil, e Sérgio Santeiro, da revista Filme Cultura, exposto abaixo - , mas também pode ser encontrado na própria narrativa do filme. Logo, não se trata apenas de "reconstruir" o filme de acordo com suas intenções (ou capacidades), mas de "construir" o sentido com o filme. 
Ely Azeredo (1979, p. 2) indica, de partida, que compreende as opções de Saraceni por não "desenvolver um trabalho rigorosamente histórico", preferindo o tom lírico. Contudo, também aponta os esforços de uma reconstituição bem realizada, no sentido de "reproduzir com empenho [...] o Brasil quinhentista, os ambientes, as gentes, e permanecer fiel a uma certa fantasia indianista, ultrapassada”. Apesar do desprezo por essa leitura, Azeredo demonstra seu esforço em "esquecer o compromisso com o documento real" em prol da leitura utópica, concluindo que os intentos de Saraceni não foram bem-sucedidos, nem como "documento real" nem como utopia.

Em resposta a essa crítica, Sérgio Santeiro (1979, p. 2) escreve uma carta indignada, enviada para a seção "Leitores", reclamando do "descaso pela produção nacional”, conclusão a que chegou após perceber a "banalização" do filme perpetrada por Azeredo. Assim, a "belíssima visão de um Anchieta entre o sublime e o profano, glosando a vida da própria vida brasileira na crônica política de nosso quinhentismo, cede no interesse da triste página do suplemento às mais ridículas afirmações". Em crítica publicada na Filme Cultura (1980, p. 29s), no início do ano seguinte, Santeiro defende mais acuradamente seu ponto de vista: "Quando se dispôs a contar essa história da colonização, tenho como certo, e bem o demonstra o filme, que Saraceni tinha os olhos no nosso tempo, redescobrindo o passado [...] como a prática do tempo presente".

Até aqui parece concordar com Azeredo e continua ao afirmar que "infelizmente, ou não, a história é um conceito, ninguém a vive de fato porque a vida humana contida pela morte pode no máximo ser uma existência biográfica". Saraceni, consciente desses limites, teria se lançado num ensaio histórico pleno de liberdade poética, procurando ultrapassar limites do tempo cronológico da biografia de Anchieta, estendendo a temporalidade do filme para o presente (da produção), procurando unir biografia e História. Ao fim, conclui que Anchieta era uma “inspiradíssima versão [dos primeiros tempos de vida colonial] que, se não foi bem acolhida, certamente deve-se mais à pobreza dos tempos em que vivemos do que à generosidade com que os artistas se têm dedicado a descobrir o país". 
É possível perceber que ambos concordam quanto ao dualismo que perpassa a obra, discordando apenas do resultado: para Azeredo, que parece "tolerar" a ficcionalização, o resultado final não teria soado convincente como um "filme histórico", ainda que moderno; já para Santeiro, era justamente a ficcionalização que permitia ao filme ser "histórico", de forma mais complexa do que seria uma cinebiografia tradicional. Para ambos, a ambiguidade é o caráter mais forte da película - sendo encarada como entrave para um, e como essencial para o outro. De qualquer forma, são os sentidos históricos que se põem em disputa, o que valida o filme como agente da cultura histórica.

\section{Considerações finais: modos de ver}

A história está presente em Anchieta, José do Brasil não da forma como ela surgiria em um épico clássico: afinal, o filme busca uma linguagem alternativa. Ainda que, se comparada a outros filmes do período, não apresente uma experimentação radical, a obra está longe do espetáculo histórico no estilo de Independência ou morte. Nele, a história aparece objetivada, quando Anchieta afirma que vive em pleno esplendor do Renascimento, o que obviamente é uma construção histórica, já que quem vivia no Renascimento não sabia disso. Em outra sequência, Anchieta diz ouvir vozes do futuro acusando os jesuítas de destruírem as populações indígenas ao espalharem doenças entre eles. É a voz da história de seus atos, construída no futuro; voz que ele se recusa a ouvir, seguindo adiante em seus propósitos.

Essa personificação da história - que permite um diálogo dela com uma personagem - não é possível em um épico clássico. Nesse, os únicos que devem saber da existência da história são os espectadores. As personagens da trama, ao contrário, devem viver a história sem ter consciência disso. Aqui fica reforçado o futuro do pretérito (PINTO, 2005) como o "tempo verbal" dos filmes históricos modernos: Anchieta ouve vozes de seu futuro, que é, de fato, o presente do filme. O passado é representado a partir de uma "contaminação" do presente. Afinal, só um Anchieta que estivesse no presente (1979), narrando sua atuação no século XVI, poderia saber que viveu em pleno esplendor do Renascimento. 
Ainda assim, o filme foi disputado e, em torno dele, tentou-se delimitar o caráter da história contada: se fiel ou não, se política, religiosa, de direita ou de esquerda, entre outros. Retomo aqui a expressão de Lowenthal (1988) para se referir às representações da história: factions (síntese de "fato" e "ficção", em inglês). Mais que um jogo de palavras, o autor realiza com o neologismo uma complexa leitura dessas representações, conjunto em que incluo os filmes "históricos": ao mesmo tempo miméticos e imaginados em relação ao passado. Defendi ao longo deste texto que, além de inerente ao "específico" dessas obras, o status de factions aparece também nos modos de ver, como defendido por Roger Odin (2005, 2011): há, a priori, um modo de olhar "documentarizante" lançado sobre os filmes históricos - não porque se tende a acreditar no referencial das filmagens, como no gênero documentário, mas porque se tende a crer no referencial da diegese. Porque é histórico, é real. Mesmo em um filme como Anchieta, em que esse falso truísmo é contestado na diegese, na narrativa e no espaço de comunicação, a tendência é se apropriar dele como um objeto cuja posse pudesse garantir o domínio sobre a história. Ainda assim, a obra escapou às amarras, permanecendo sob o signo da ambiguidade. 


\section{Referências}

AMANCIO, T. Artes e manhas da Embrafilme: cinema estatal brasileiro em sua época de ouro - 1977-81. Niterói: EDUFF, 2001. BERNARDET, J. C. “Qual é a história?” In: BERNARDET, J. C. et al. Anos 70. V. 4 (Cinema). Rio de Janeiro: Europa, 1979.

BERSTEIN, S. "Enjeux. l'historien et la culture politiques". Vingtième Siècle - Revue d'histoire, n. 35, 1992.

CAMPO, M. B. O desafio e as vicissitudes político-culturais das esquerdas no pós-64. Dissertação (Mestrado) - Universidade de São Paulo, São Paulo, 1995.

“O desafio: filme reflexão no pós-1964”. In:

CAPELATO, M. H. et al (Orgs.). História e cinema. São Paulo: Alameda, 2011.

CARDOSO, M. "Glauber Rocha: exílio, cinema e História do Brasil”. In: CAPELATO, M. H. et al (Orgs.). História e cinema. São Paulo: Alameda, 2011.

Disponível em: <seer.bce.unb.br/index.php/emtempos/article/ download/2552/2106>. Acesso em: 11 ago. 2013.

FIGUEIRÔA, A. Cinema Novo: a onda do jovem cinema e sua recepção na França. Campinas: Papirus, 2004.

FLECK, E. C. D.; MATOS, F. U. “Anchieta, José do Brasil: cinema, representação e memória em tempos de ditadura militar”. Em tempo de histórias - Publicação do Programa de Pós-Graduação em História da Universidade de Brasília, n. 16, Brasília, jan.-jul. 2010.

GOMES, A. C. Cultura política e cultura histórica no Estado Novo. In: ABREU, M. et al. Cultura política e leituras do passado. Rio de Janeiro: Civilização Brasileira; Rio de Janeiro: Faperj, 2007.

KORNIS, M. A. "História e Cinema, um debate metodológico". Estudos Históricos, Rio de Janeiro, v. 5, n. 10, 1992.

LEUTRAT, J.-L. "Uma relação de diversos andares: cinema e história”. In: Imagens. Campinas, n. 5, ago-dez 1995. 
LOWENTHAL, D. The past is a foreign country. Cambridge: Cambridge, 1988.

MACHADO, R. "O cinema paulistano e os ciclos regionais sulsudeste (1912-1933)”. In: RAMOS, F. História do cinema brasileiro. São Paulo: Círculo do Livro, 1987.

MALAFAIA, W. V. "Deus e o Diabo no Cinema Novo: religiosidade e messianismo a 24 quadros". In: VIII ENCONTRO REGIONAL DE HISTÓRIA. Anais. Rio de Janeiro, 1998. Disponível em: < http://www.rj.anpuh.org/conteudo/view?ID_CONTEUDO=307>. Acesso em: 13 ago. 2013.

MORETTIN, E. V. “O cinema como fonte histórica na obra de Marc Ferro". História: questões e debates, Curitiba, n. 38, 2003.

Os limites de um projeto de monumentalização cinematográfica: uma análise do filme "O descobrimento do Brasil" (1937). Tese (Doutorado) - Escola de Comunicações e Artes, Universidade de São Paulo, São Paulo, 2001.

"Produção e formas de circulação do tema

Descobrimento do Brasil: uma análise de seu percurso e do filme Descobrimento do Brasil (1937), de Humberto Mauro". Revista Brasileira de História, v. 20, n. 39, 2000.

NAPOLITANO. M. "A escrita fílmica da história e a monumentalização do passado: uma análise comparada de Amistad e Danton”. In: CAPELATO, M. H. et al (Orgs.). História e cinema. São Paulo: Alameda, 2011.

NOVA, C. “A 'História' diante dos desafios imagéticos”. Projeto História - história e imagem, São Paulo, n. 21, nov. 2000.

ODIN, R. "Aquestão do público: uma abordagem semiopragmática”. In: RAMOS, F. (Org.). Teoria contemporânea do cinema. V. 2. São Paulo: Senac SP, 2005.

. "Filme documentário, leitura documentarizante".

Significação, São Paulo, n. 37, jan.-fev. 2012.

Les espaces de communication. Introduction à la sémio-pragmatique. Paris: Presses Universitaires de Grenoble, 2011. 
ORTIZ, R. Cultura brasileira e identidade nacional. São Paulo: Brasiliense, 1986.

PINTO, C. E. P. “A história numa sala escura... a construção da memória nacional através de filmes históricos durante a ditadura civil-militar". Cantareira, v. 2, ano 1, ed. 7, 2005.

Imaginar a cidade real: o Cinema Novo e a representação da modernidade urbana carioca (1955-1970). Tese (Doutorado) - Universidade Federal Fluminense, Niterói, 2013.

.O futuro do pretérito: a representação da história em filmes cinemanovistas (1968-1980). Dissertação (Mestrado) Pontifícia Universidade Católica do Rio de Janeiro, Rio de Janeiro, 2005.

. "Todos os desafios do mundo: a geração de 1964 no Cinema Novo". Tempos Históricos, Marechal Cândido Rondon (PR), v. 1, n. 1, 1' semestre 2011.

- "Tudo deve falar do Golpe? Os limites da ditadura civil-militar como chave interpretativa da representação urbana nos filmes do Cinema Novo". Revista Contemporânea, ano 3, n. 3, 2013b.

RAMOS, F. (Org.). História do cinema brasileiro. São Paulo: Círculo do Livro, 1987.

RAMOS, J. M O. Cinema, Estado e lutas culturais: anos 50, 60 e 70. Rio de Janeiro: Paz e Terra, 1983.

REIS FILHO, D. A. A revolução faltou ao encontro. São Paulo: Brasiliense, 1991.

RODRIGUES, A. "Os anos Embrafilme (1974/1987)". Ciclo de Cinema Brasileiro (catálogo). Lisboa: Cinemateca Portuguesa; Lisboa: Fundação Calouste Gulbenkian, 1987.

ROLLEMBERG, D. Exílio: entre radares e raízes. Rio de Janeiro: Record, 1999.

ROSENSTONE, R. A história nos filmes, os filmes na história. São Paulo: Paz e Terra, 2010.

SARACENI, P. C. Por dentro do Cinema Novo: minha viagem. Rio de Janeiro: Nova Fronteira, 1993. 
VADICO, L. "O épico bíblico hollywoodiano: o espetáculo como estética da salvação". Rebeca, ano 1, edição 2, n. 2, jul.-dez. 2012. VIANY, A. O processo do cinema novo. Rio de Janeiro: Aeroplano, 1999.

XAVIER, I. O cinema brasileiro moderno. São Paulo: Paz e Terra, 2001.

\section{Periódicos}

AZEREDO, E. "A utopia de Saraceni”. Jornal do Brasil, 23 mar. 1979, p. 2.

SANTEIRO, S. Cartas: "Cinema”. Jornal do Brasil, 28 mar. 1979, Caderno B, p. 2. SANTEIRO, S. "Seção Crítica. 'Anchieta, José do Brasil”. Filme Cultura, ano XIII, n. 34, jan.-mar. 1980.

FILME CULTURA. "A hora e a vez dos filmes históricos" (Suplemento Movimento), ano IV, n. 18, jan.-fev. 1971. 